NOTES

\title{
TAXATION: PREPAID INCOME DEFERRALS AND THE "CLAIM OF RIGHT" DOCTRINE
}

Since I9I6 accrual basis accounting has been permitted as a general method of computing taxable income, subject only to the requirement that it clearly reflect income. ${ }^{1}$ Despite statutory authorization of this method of tax computation, the judicially-derived "claim of right" doctrine has been invoked against taxpayers who, acting in accordance with accepted principles of accrual accounting, attempt to defer prepaid receipts to the period when earned.

This doctrine states that, "If a taxpayer receives earnings under a 'claim of right' and without restriction as to its disposition, he has received income which he is required to return, even though it may still be claimed that he is not entitled to retain the money, and even though he may still be adjudged liable to restore its equivalent. ..."2 The doctrine was originally enunciated in North American Oil Consolidated v. Burnet. ${ }^{3}$ It was then promptly applied in Brown v. Helvering,

\footnotetext{
${ }^{2}$ Beginning with the Revenue Act of 1916 , taxpayers were permitted to return income using the method of accounting with which their accounts were kept. Revenue Act of 1916 , ch. $46_{3}, \S 8(\mathrm{~g}), 39$ Stat. $76_{3}$ (individuals), and $\S_{13}(\mathrm{~d}), 39$ Stat. 771 (corporations). Although the statutes failed to mention the accrual basis by name, the committee reports, H.R. REP. No. 922, 64th Cong., Ist Sess. (1916), reprinted 1939-x, Part 2 Cum. Bull. 22, and the regulations in effect under the Act, Treas. Reg. 33 $\S \S 126,180$ (1918), expressly approved the accrual basis as an acceptable accounting method under the Act. The present general tax accounting statute, substantially unchanged over the years, provides that: "Taxable income shall be computed under the method of accounting on the basis of which the taxpayer regularly computes his income in keeping his books." INT. REv. CODE of x 954, § 446(a). The statute also lists the accrual basis as one of the permissible methods of accounting. INT. REv. CODE OF 1954, $\S 446(c)(2)$.

The Code also provides that income may be returned in a year other than that of receipt when, under the inethod of accounting used in computing taxable income, such amounts are to be properly accounted for in a different period. INT. REv. CoDE OF 1954, $\S_{45}$ I. Deductions are to be taken in the proper taxable year as determined under the method of accounting used in computing taxable income. INT. REv. CODE OF 1954, $\S 461$.

${ }^{3}$ North American Oil Consol. v. Burnet, 286 U.S. 417, 424 (1932).

${ }_{2}^{3} 86$ U.S. 417 . The taxpayer's possession of certain oil fields was disputed by the government, which in 1916 initiated a suit to oust the taxpayer and at the same time secured the appointment of a receiver to operate the fields and hold the profits. In 1917 , following dismissal of the government's suit, the net profits of 1916 were released to the taxpayer. Final settlement of the action was not reached until 1922, when the
} 
where an accrual basis taxpayer, who received overriding commissions on the sale of insurance policies, was taxed on the full amount of the commissions in the year of receipt, even though he was obligated to return a portion of them should a policy be cancelled prior to its expiration date. Relying both on the taxpayer's previous treatment of the commissions as income when received and on the finding of the Board of Tax Appeals ${ }^{5}$ that there was no proof that the overriding commissions contained any element of compensation for services to be rendered in future years, the Court rejected the taxpayer's argument that the commissions were unearned and should be prorated over the lives of the policies. Because the Court regarded the commissions as earned and retained without contractual or other restrictions, it held that they were taxable in the year of receipt under the "claim of right" doctrine. The taxpayer's alternative attempt to deduct from the reported commissions estimated amounts that would be returned due to future cancellations was also disallowed on the ground that no liability accrues during the taxable year on account of expected future cancellations. Unless the events fixing the liability occur during the taxable year, the liability remains contingent and cannot accrue except where specifically provided by statute. ${ }^{8}$

Despite the Court's clear acknowledgment in both cases that it was dealing with earned amounts, the North American and Brown decisions have been cited as authority for the proposition that money received without restriction upon its use or disposition is taxable in the year received even though some portion may be unearned. ${ }^{7}$ Under this inter-

government's appeal was dismissed. As indicated in the quoted passage, the Court held the profits taxable to the taxpayer in 1917 , the year of receipt, and not in 1922, when the dispute was finally settled. The Court also held that the profits were not income for 1916, the taxpayer having no right to them until 1917 when the court ordered the funds to be paid over.

291 U.S. 193 (1934).

Brown v. Helvering, 22 B.T.A. 678 (1931).

- See, e.g., reserve for bad debts, INT. REv. CoDE of 1954, $\$ 166$ (c).

${ }^{7}$ South Dade Farms, Inc. v. Commissioner, I38 F.2d 818, 819 (5th Cir. 1943); Automobile Club of Michigan v. Commissioner, 20 T.C. 1033, 1046 (1953). This use of the doctrine to tax prepaid income has been criticized by some writers. Sidney Gelfaud, who represented the taxpayer in Bressner Radio, Inc. v. Commissioner, infra note 25, reviews the doctriue's history and its effect on prepaid income in The "Claim of Right" Doctrine, 33 Taxes 726 (1955). See also, Sporrer, Past and Future of Deferring Income and Reserving for Expense, 34 TAxEs 45, 46-49 (1956); Jacobs, Changing Attitudes Toward Accrual Concepts, N.Y.U. I6TH INST. ON FED. TAX 579 (1958); Heffern, Claim-of-Right and Other Tax Doctrines Are Distorting Proper Accounting, $5 \mathrm{~J}$. Taxation 20 (1956). Mr. Justice Harlan felt that the use of the doctrine should be restricted to "determining whether the treatment of an item of income should be in- 
pretation taxpayers have been required to report as income in the year of receipt funds attributable to prepaid club dues, ${ }^{8}$ coupons obligating the taxpayer to render future services, ${ }^{9}$ tuition for future dance lessons, ${ }^{10}$ and prepaid rent. ${ }^{11}$

Congress recognized the inconsistencies between the language of the accounting statutes and their application, ${ }^{12}$ and, in an attempt to harmonize tax accounting with generally accepted accounting principles, ${ }^{13}$ enacted sections $452^{14}$ and $462^{15}$ of the I954 Code which re-

fuenced by the fact that the right to receive or keep it is in dispute; it does not clearly relate to the entirely different question whether items that admittedly belong to the taxpayer may be attributed to a taxable year other than that of receipt, in accordance with the principles of accrual accounting." Automobile Club of Michigan v. Commissioner, 353 U.S. I90, I90-91 (1957) (dissenting opinion).

For proper applications of the claim of right doctrine under this view, see Mutual Tel. Co. v. United States, 204 F.2d I60 (gth Cir. 1953) (where earnings received under a claim of right, but with restrictions imposed on their disposition, were held not taxable in the year of receipt), and Bates Motor Transp. Line Inc. v. Commissioner, $200 \mathrm{~F} .2 \mathrm{~d} 20$ (7th Cir. 1952) (where, since the amount of refund could not be determined until after the close of the taxable year, the taxpayer was required to return overpayments for services rendered as income in the year of receipt).

-Automobile Club of New York v. Commissioner, 32 T.C. No. 79 (1959); Your Health Club, Inc. v. Commissioner, 4 T.C. 385 ( 1944 ).

${ }^{\circ}$ South Tacoma Motor Co. v. Commissioner, 3 T.C. 4 I I (1944). Accord, National Airlines, Inc. v. Commissioner, 9 T.C. I59 (1947) (unused transportation tickets).

${ }^{10}$ Andrews v. Commissioner, 23 T.C. 1026 (1955).

${ }^{11}$ New Capital Hotel, Inc. v. Commissioner, 28 T.C. 706 (1957), aff'd, 261 F.2d 437 (6th Cir. 1958).

${ }^{13}$ The inconsistencies stem fundamentally from the different goals sought by financial and tax accounting. Financial accounting is designed to determine the present and future earning power of a business, while the primary purpose of tax accounting is to measure the taxpayer's present ability to make an immediate cash payment of his tax. See Exbacher, Federal Income Tax Accounting vs. Accepted Accounting PrinciplesFrom a Lawyer's Viewpoint, 22 U. KAN. CITY L. REv. 57 (1953-54); Hylton, Disadvantages in Conforming Taxable Income to Good Accounting Concepts, $3 \mathrm{~J}$. TAXATION 274 (1955), favoring recognition and maintenance of tax and financial accounting as distinct systems.

${ }^{23}$ S. REP. No. 1622,83 d Cong., $2 d$ Sess. 62 (1954).

${ }^{14}$ INT. REv. CODE OF 1954, ch. $736 \S 452,68 \mathrm{~A}$ Stat. 152, permit accrual basis taxpayers to defer prepaid income which gave rise to a liability, extending beyond the close of the taxable year, to render services, furnish goods or other property, or allow the use of property, to the year or years in which the income would be earned. The period of deferral for any one prepaid iten was not to exceed five years except by consent of the Secretary or his delegate.

${ }^{15}$ INT. REv. CODE OF I954, ch. $736, \S 462,68 \mathrm{~A}$ Stat. 158 , provided for the deduction of reasonable additions to reserves for estimated expenses. The additions were subject to a discretionary reduction by the Secretary or his delegate, if considered excessive.

For a report of the intended effect of $\$ \S 452$ and 462 , see S. REP. No. $1622,83 \mathrm{~d}$ Cong., 2d Sess. 301-03, 305-07 (1954). Sections 452 and 462 were extensively re- 
spectively permitted the deferral of prepaid income and the establishment of reserves for estimated expenses. At the insistence of the Treasury, section 462 was retroactively repealed ${ }^{16}$ due to anticipated revenue loss, litigation, and abuse of the statutory provisions. ${ }^{17}$ Section 452 was repealed at the same time to prevent the accomplishment of the same ends. ${ }^{18}$

Despite its early repeal, the enactment of section 452 stimulated judicial appreciation of accrual accounting principles and prompted closer examination of disputed accounting methods in the light of the statutory requirement that accounting methods clearly reflect income. Deferral of prepaid subscription income over the life of the subscription was approved in Beacon Publishing Co. $v$. Commissioner, ${ }^{10}$ while in Schuessler v. Commissioner ${ }^{20}$ a taxpayer was permitted to deduct the estimated expense of performance from reported advance payments under contracts obligating him to turn gas furnaces off and on each year over a five-year period. Then came Automobile Club of Michigan v. Commissioner, ${ }^{21}$ the only case involving prepaid income to reach the Supreme Court since Browen v. Helvering. In that case club dues obligating the taxpayer to render emergency road service upon demand were received a year in advance. To reflect its liability arising from receipt of the dues, the taxpayer had credited one-twelfth of the dues to

viewed and interpreted in Bierman \& Hellerstein, Accounting for Prepaid Income and Estimated Expenses Under the Internal Revenue Code of 1954, 10 TAX L. REv. 83 (1954). For a shorter treatment, see Austin, Surrey, Warren, and Winchov, The Internal Revenue Code of r954: Tax Accounting, 68 HARV. L. REV. 257, 268-70, 27376 (1954).

${ }_{18}$ P.L. 74, 84th Cong., § I (b), 69 Stat. 134 (1955).

${ }^{17}$ See Hearings Before the Committee on Finance, United States Senate, H.R. 4725, 84th Cong., ist Sess. (1955) and Hearings Before the Commitlee on Ways and Means, House of Representatives on H.R. 4725, 84th Cong., ist Sess. (1955). For a short report of the repeal see Wagnan, Sections 452 and 462 : Stormy Past but a Bright Tomorrow, 33 TAXES 711, 715-17 (1955).

${ }^{18}$ P.L. 74, 84th Cong. \$1 (a), 69 Stat. 134 (1955). Although it went along with the repeal, the Senate indicated that it favored the effect $\$ \S 452$ and 462 would have in harmonizing tax and financial accounting, and that it would attempt to devise substitute provisions for them. S. REP. No. 372, 84th Cong., 4-6 Ist Sess., reprinted at 1955-II CUM. BULL. 858, 860-61.

${ }_{10} 218$ F.2d 697 (1oth Cir. 1955). "Plainly ... [the statute] ... contemplates that prepaid sums can be returned in a year other than when received." Id. at $70 x$. The Beacon decision has been codified in INT. REv. CoDE OF 1954, $\$ 455$.

${ }^{20} 230$ F.2d 722 (5th Cir. 1956) "Clearly what is sought by this statute is an accounting method that most accurately reflects the taxpayer's income on an annual accounting basis." Id. at 724 .

${ }_{22} 353$ U.S. $180(1957)$. 
prepaid income each month. The Commissioner, applying the "claim of right" doctrine, required that the dues be taxed in full in the year of receipt, and his determination was upheld by the Tax Court and the Court of Appeals. In its affirmance of this decision, however, the Supreme Court did not expressly rely on the "claim of right" doctrine, but based its decision on its finding that the taxpayer's deferrals in monthly amounts were purely artificial and bore no actual relation to the services which it might be required to render, and therefore failed clearly to reflect income. ${ }^{22}$ The Beacon and Schuessler cases were distinguished as applying only to those situations where the taxpayer was required to perform specified services on fixed dates after the close of the tax year. Some writers interpreted the Court's decision in Automobile Club of Michigan as requiring a fixed date for performance for the proper deferral of prepaid income, ${ }^{23}$ while others felt that, under the language of the decision, a pro rata deferral might be sustained in the absence of a requirement for fixed services or specified performance dates if the monthly allocations bore an accurate statistical relationship to the actual service to be performed. ${ }^{24}$

This latter view was adopted in Bressner Radio, Inc. v. Commissioner, ${ }^{25}$ a recent case involving deferrals of receipts derived from service agreements offered as an inducement to prospective purchasers of television sets. ${ }^{26}$ The court found that income is clearly reflected where the

\footnotetext{
22 Id. at $189-90$.

${ }^{23}$ Heffern, New Ruling Forecasts IRS Extension of Claim of Right, 9 J. TAxatron 202, 203 (1958), and Note, Prepaid Income Held Taxable in the Year of Receipt, 1957 U. ILL. L.F. 517,522 (1957).

"Hoffman, Accounting Treatment Counts in Determining Net Taxable Income, 35 TAXES 918, 921 (1957); Note, Taxation of Prepaid Income: A Temporary Solution, 67 YALE L.J. 1425,1439 (1958).

A more disturbing aspect of the Automobile Club of Michigan case, from the standpoint of those advocating income deferrals, was the Court's view that the accounting statute vests the Commissioner with broad discretion to determine whether an accounting method clearly reflects income. Accord, Commissioner v. Hansen, 360 U.S. 446 (1959). See Heffern, supra note 23 , at 203 .

${ }_{26} 67$ F.2d 520 (2d Cir. 1959).

20 The taxpayer, a retail dealer in television sets, offered to the purchasers of its sets a twelve-month service contract covering installation, adjustment, and replacement parts. At the end of each taxable year in which the service agreements were in effect, a large number of contract months remained to be covered. Reporting income from the contract receipts, the taxpayer followed a consistent plan of income deferral, charging $25 \%$ of each contract price to installation income and reporting the balance as service income over the life of the contract on a monthly pro rata basis. At the end of each taxable year in which receipts were deferred, the taxpayer had on hand a cash balance and inventory of replacement parts whose combined value exceeded the total receipts deferred in that year. Throughout the periods covered by the contracts, the taxpayer
} 
taxpayer offers ample statistical proof that he was subjected to a uniform demand for services throughout the contract period and where his monthly allocations were completely absorbed by the cost of servicing. In Bressner, the court overcame the "claim of right" doctrine by pointing out that originally "the Court held only that money that was earned and held under a claim of right was includible in the year of receipt."27 The court found no interpretation of the doctrine in subsequent cases which would justify its being used to tax prepaid income in the year of receipt. It distinguished the Broron decision by the failure of the taxpayer in that case to prove that the commissions were unearned when received. ${ }^{28}$

Bressner reaches a logical result in view of its compelling factual situation, but the facts themselves limit the value of the decision as precedent for deferring income where indefinite services are rendered upon demand. For instance, only that portion of the contract receipts which related to the taxpayer's liability to render future services was deferred. Twenty-five per cent of each contract price, an amount closely approximating the actual cost of installation, ${ }^{20}$ was reported as income in the year of receipt. The length of the deferral period was short and definite. Since no part of the prepaid receipts could escape taxation for more than a year following receipt, the deferral created no greater taxcollection hazard than exists where a taxpayer receives income on the first day of the taxable year. Where the deferral period is indefinite ${ }^{80}$ or long-term, or where the entire prepayment is deferred for inclusion in a later period, ${ }^{31}$ the courts should be less inclined to approve the deferral. Although under no contractual obligation to create and maintain a reserve, the taxpayer evidenced cognizance of his legal liability to service the television sets by maintaining a cash balance and inventory which exceeded the value of the deferred amounts and approximated a

was subjected to a uniform demand for service, averaging 8 to 12 visits per set. An overall loss was sustained on the fulfillment of each year's service obligation. The Commissioner required that the deferred sums be taxed in the year of receipt. The Tax Court upheld his determination on the grounds that ( $x$ ) the receipts were held without restriction as to their use or disposition, and (2) the monthly allocation of the service receipts was purely artificial and bore no relation to the services the taxpayer might in fact be called upon to render. 28 T.C. 378 (1957).

${ }_{27} 67$ F.2d at 525 .

${ }^{28}$ Id. at 525-26.

${ }^{20}$ The price per contract was between $\$ 80$ and $\$ 100$. The cost of installation was approximately \$19: \$7 for anteuna, \$10 labor, and $\$ 2$ clerical overhead. Id. at $\$ 21$.

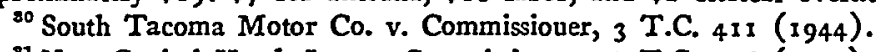

${ }^{31}$ New Capital Hotel, Inc. v. Commissioner, 28 T.C. 706 (1957). 
trust fund. ${ }^{32}$ In cases where a taxpayer fails to restrict his use of the prepayments, ${ }^{33}$ he may encounter difficulty in sustaining their deferral.

A more significant factor of the case is the fact that an over-all loss was sustained in fulfilling the contracts. ${ }^{34}$ Where the income-producing transaction results in a loss, the government's insistence that income be reported in a particular period is less compelling because the loss may be transferred from one period to another. ${ }^{35}$ But where a profit results, the allocation may be deemed artificial even though the demand for service is uniform, since the requested services may vary as to their cost, thus giving rise to high profits in one tax period and low profits in another. A practical solution to such problems, and to the whole problem of prepaid income, would be a completed contract arrangement, similar to that authorized for use by taxpayers in the construction trades, ${ }^{36}$ through which the reporting of all income and expenses arising from a particular contract is deferred to the year in which the contract is completed, thereby achieving a truer reflection of income. ${ }^{37}$

The Bressner decision, relying on the Supreme Court's opinion in Automobile Club of Michigan, would reject the Commissioner's established practice of applying the "claim of right" doctrine to tax prepaid income in the year of receipt, and would permit such deferrals as are statistically supported as clearly reflecting income. Although it is desirable to have the income tax follow generally recognized accounting principles, situations may arise wherein these principles must give way to practical convenience. By requiring that prepaid income be reported in the year of receipt, the "claim of right" doctrine lays down a clear administrative standard for determining the tax period when income must be returned. Any attempt to follow the Bressner case and to permit prepaid income to be deferred would involve judicial inquiry into whether, in the given situation, there is a relation between the income received and the time when it was earned which would justify such deferral. Since this is largely an ad hoc question, one case could seldom be regarded as a controlling precedent for another. The result might

\footnotetext{
${ }^{82} 267$ F.2d at 522 .

${ }^{53}$ Phillips v. Commissioner, 238 F.2d 473 (7th Cir. 1956).

34267 F.2d at 524.

${ }^{85}$ INT. REv. CODE OF 1954, § 172 .

${ }^{30}$ Treas. Reg. $\$ 1.45 \mathrm{I}-3$ (1957), available to taxpayers engaged in building contracts which will extend for more than one year from date of execution to date of completion.

${ }^{{ }^{7}}$ For a discussion of the long-term contract method of accounting see Wagman, Tax Accounting for Long-Term Contracts, 33 TAXES 277 (1955).
} 
well bring an increase in litigation and administrative uncertainty, ${ }^{88}$ which would more than offset any theoretical symmetry achieved by a strict application of the accrual theory of accounting to the income tax.

${ }^{88}$ An example of the confusion that might result can be derived from Automobile Club of New York, Inc. v. Commissioner, 32 T.C. No. 79 (1959), where the Tax Court, denying the taxpayer's deferral of prepaid club dues delivered four separate opimions expressing their interpretation of the effect of Bressner on prepaid income deferrals. 